\title{
The Effectiveness of Tax Incentives for Business R\&D in Russia and Abroad
}

\author{
Irina Evgenievna Ilina
}

\author{
Russian Scientific Research Institute of Economics, Politics and Law in Science and Technology \\ Email:skvo_ie@mail.ru \\ Svetlana Evgenievna Ushakova
}

Russian Scientific Research Institute of Economics, Politics and Law in Science and Technology

Email: svetlanaush804@yandex.ru

\section{Doi:10.5901/mjss.2015.v6n3p331}

\begin{abstract}
Aim. The article presents the international experience of introducing tax incentives for research and development in the business sector, the investigation of the possibility of assessing the effectiveness of tax incentives and their impact on the share of expenditure on research and development in the country's GDP. Some recommendations for the improvement of tax support for enterprises conducting research and development are done on the example of Russia.Method. In the article the analysis of existing tax measures to support enterprises is presented. Evaluation of the influence of the introduction of indirect tax incentives for the increase in the share of expenditure on research and development in the country's GDP was performed by the method of correlation-regression analysis. Results. The study showed that not all cases of indirect tax incentives lead to an increase in the share of research and development in the cost structure of enterprises. Tax incentives should be reviewed regularly in accordance with the analysis of changes in key macroeconomic indicators showing the level of innovativeness of the economy. The introduction of tax incentives for $R \& D$ expenditure of business may give a positive socio-economic impact.Conclusion. Tax incentives are one of the instruments to encourage the market development of the RIA, which can have a positive impact on the supply of new products and technologies, as well as on their demand.
\end{abstract}

Keywords: research and development, tax incentives, results of intellectual activities

\section{Literature Review}

Tax incentives are one of the most effective indirect tools for stimulating business enterprises to conduct research and development (R\&D) and use the results of their intellectual activities (RIA), which are widely used in the world today. Enterprises of the commercial sector of economy make their investment decisions primarily based on the goal of obtaining the maximum profit, including through minimization of costs of goods and services production. The combination of product quality growth and reduction of its production cost and as a result the reduction of its market price increases the competitiveness of an enterprise. R\&D are the instrument for improving the quality of the product and reducing of its cost production. On the other hand conducting R\&D always involves considerable financial costs for an enterprise. Tax incentives for the enterprises conducting R\&D can be an effective form of indirect government support for these enterprises which reduces the cost of the production of high-tech products, and hence brings more profit to commercial enterprise.

Tax incentives become more and more popular in Russia and other countries all over the world. This form of indirect government support is used in USA, France, Canada, the Netherlands, Spain, Great Britain, Belgium, China, Brazil, India, South Africa and many others. This form of indirect government support of business R\&D and market development of RIA in Russia and other countries become increasingly important in the whole complex of measures aimed at stimulating R\&D in the business sector (Gokhberg, Kitova, Rud', 2014).

It should be noted that in recent years the role of tax incentives for R\&D in the business-sector of economy is increasing in the countries with a high portion of direct government participation in the financing of scientific and technical sphere. These countries include, for example, Norway, where in recent years attempts have been made to increase the share of private business in R\&D (Klavdienko, 2014). Russia also holds one of the first places in terms of direct government funding for R\&D, including those carried out in the business sector. During the period 2001-2011 the amount of direct government funding for R\&D increased by $9.63 \%$ to $58.67 \%$ of all R\&D undertaken in the business sector. In 
recent years along with the high level of direct public funding of R\&D in Russia it was introduced a whole range of additional fiscal measures aimed at stimulating R\&D (Feoktistova, 2014).

With the increasing of popularity of tax incentives worldwide, evaluating of their effectiveness and their impact on the growth of business enterprise expenditure on R\&D becomes of the particular importance for management decisions at the state level to improve and adjust them.

\section{Research Methods}

Based on OECD statistics the existing measures of tax incentives for business R\&D were analyzed. The existing measures of tax incentives, their description and the list of countries in which they are used are represented in the Table 1.

Table 1. Measures of tax incentives, their description and the list of countries in which they are used

\begin{tabular}{|c|c|c|}
\hline Measures of tax incentives & The description of tax incentives & $\begin{array}{l}\text { Countries where tax } \\
\text { incentives are used }\end{array}$ \\
\hline $\begin{array}{l}\text { The income tax rate reduction ("Patent } \\
\text { Box") }\end{array}$ & $\begin{array}{l}\text { The income tax rate depends upon the use of qualified } \\
\text { intellectual property objects. The effective tax rate is } \\
\text { determined by the share of income that is not taxable } \\
\text { according to the country tax legislation. }\end{array}$ & $\begin{array}{l}\text { Belgium, France, Hungary, } \\
\text { Luxembourg, the Netherlands, } \\
\text { Spain, Great Britain }\end{array}$ \\
\hline $\begin{array}{l}\text { The reduction or annulment of the } \\
\text { income tax rate on profits from the sale } \\
\text { of stocks of innovative companies }\end{array}$ & $\begin{array}{l}\text { The reduction or annulment of the income tax rate on } \\
\text { profits from the sale of stocks of innovative companies } \\
\text { takes place if the investor was in possession of stocks } \\
\text { of an innovative company for several years }\end{array}$ & Belgium, USA \\
\hline Allowance for value-added tax & $\begin{array}{l}\text { Reduced tax rates, or the application of differential rates } \\
\text { for high-tech products }\end{array}$ & $\begin{array}{l}\text { Great Britain, Germany, Spain, } \\
\text { Sweden }\end{array}$ \\
\hline $\begin{array}{l}\text { Write-off the R\&D costs with an } \\
\text { increasing coefficient }\end{array}$ & $\begin{array}{l}\text { The tax credit is calculated either on the volume of R\&D } \\
\text { expenditures or on gains } R \& D \text { expenditure. }\end{array}$ & $\begin{array}{l}\text { Australia, Austria, Belgium, } \\
\text { Great Britain, Denmark, } \\
\text { Hungary, Czech Republic }\end{array}$ \\
\hline Investment tax credit & $\begin{array}{l}\text { The compensation of the part of tax charged on the } \\
\text { profits of companies engaged in R\&D. Amount of tax } \\
\text { refund is calculated as the share of } R \& d \text { expenditures. }\end{array}$ & $\begin{array}{l}\text { Australia, Austria, Belgium, } \\
\text { Great Britain, Hungary, } \\
\text { Denmark, Canada, USA, Czech } \\
\text { Republic }\end{array}$ \\
\hline $\begin{array}{l}\text { The granting of tax holidays on } \\
\text { payment of tax on income from ongoing } \\
\text { investment projects }\end{array}$ & $\begin{array}{l}\text { Postponing the payment of tax on profits of companies } \\
\text { engaged in } R \& D\end{array}$ & China, India \\
\hline $\begin{array}{l}\text { Accelerated depreciation for R\&D } \\
\text { capital }\end{array}$ & Accelerated depreciation of fixed assets used in R\&D & $\begin{array}{l}\text { Belgium, Brazil, Britain, } \\
\text { Denmark, Canada, China, } \\
\text { Mexico, France, Poland, Chile }\end{array}$ \\
\hline $\begin{array}{l}\text { Income tax incentives for research staff } \\
\text { salaries and social contributions }\end{array}$ & $\begin{array}{l}\text { Exemption of income tax on salaries of researchers with } \\
\text { Ph.D. degree or masters, as well as to the salaries of } \\
\text { engineers, and employees of companies having the } \\
\text { status of "young innovative company" }\end{array}$ & $\begin{array}{l}\text { Hungary, the Netherlands, } \\
\text { Turkey, France }\end{array}$ \\
\hline
\end{tabular}

In addition, correlation and regression analysis was used as the basic method of statistical data analysis. On the basis of statistical data of the OECD (Table 2) correlation and regression analysis of the dependence of the rate of business R\&D as a percentage of GDP (dependent variable y) of the volume of indirect government support through tax incentives of firms conducting R\&D as share of GDP (explanatory variable $x$ ) was conducted to identify the degree of dependence between these variables. The sample included countries for which there were numeric data, and countries with a nonzero indices of indirect state support for R\&D through tax incentives. 
Table 2. Data on indirect government support measures of R\&D through tax incentives as a share of GDP (\%) and share of business expenses on R\&D as a share of GDP (\%)

\begin{tabular}{|c|c|c|c|}
\hline № & Country & Indirect government support through R\&D tax incentives $(\mathrm{x})^{1}$ & Business enterprise expenditure on R\&D (y)2 \\
\hline 1 & France & 0,2600 & 1,42 \\
\hline 2 & Canada & 0,2100 & 0,89 \\
\hline 3 & Korea & 0,2000 & 3,09 \\
\hline 4 & Belgium (2010) & 0,1800 & 1,37 \\
\hline 5 & Netherlands & 0,1500 & 0,89 \\
\hline 6 & Ireland (2010) & 0,1400 & 1,17 \\
\hline 7 & Australia (2010) & 0,1000 & 1,27 \\
\hline 8 & Austria & 0,1000 & 1,87 \\
\hline 9 & Portugal & 0,0900 & 0,69 \\
\hline 10 & United Kingdom & 0,0800 & 1,09 \\
\hline 11 & Hungary & 0,0800 & 0,75 \\
\hline 12 & Japan & 0,0700 & 2,61 \\
\hline 13 & United States & 0,0600 & 1,89 \\
\hline 14 & Slovenia & 0,0600 & 1,83 \\
\hline 15 & China (2009) & 0,0500 & 1,4 \\
\hline 16 & Denmark & 0,0500 & 2,09 \\
\hline 17 & Norway & 0,0500 & 0,86 \\
\hline 18 & Czech Republic & 0,0500 & 1,12 \\
\hline 19 & Turkey & 0,0400 & 0,37 \\
\hline 20 & Spain (2010) & 0,0300 & 0,7 \\
\hline 21 & South Africa (2009) & 0,0200 & 0,46 \\
\hline 22 & Russian Federation & 0,0200 & 0,67 \\
\hline 23 & Chile (2010) & 0,0030 & 0,16 \\
\hline 24 & Italy & 0,0030 & 0,68 \\
\hline 25 & Slovak Republic & 0,0002 & 0,25 \\
\hline
\end{tabular}

On the bases of the data of Table 2 the correlation analysis between dependent and explanatory variables was conducted. The result is presented in Table 3.

Table 3. Construction and analysis of field correlation

\begin{tabular}{|l|c|}
\hline The value of the coefficient b & 4,287645 \\
\hline Standard deviation b & 1,973139 \\
\hline The coefficient of determination R2 & 0,170333 \\
\hline F- statistics & 4,72196 \\
\hline The regression sum of squares & 2,146428 \\
\hline The value of the coefficient a & 0,82409 \\
\hline Standard deviation a & 0,213434 \\
\hline Standard deviation y & 0,674213 \\
\hline The number of degrees of freedom & 23 \\
\hline The residual sum of squares & 10,45495 \\
\hline
\end{tabular}

Analysis of the sample showed that only $17 \%$ of the variation in the share of business expenses on R\&D in GDP is explained by the factor $x$ - the share of indirect state support for $R \& D$ through tax incentives, and $83 \%$ is explained by the influence of other factors not included in the model. The relationship between the explanatory and dependent variable can be assessed as weak. Thus, we can conclude that the increase in the share of business R\&D expenditure affects a number of other factors, and it is difficult to evaluate the strength of the impact of tax incentives for business R\&D.

1 OECD (2013), "R and D tax incentives", in OECD Science, Technology and Industry Scoreboard 2013: Innovation for Growth, OECD Publishing. http://dx.doi.org/10.1787/sti_scoreboard-2013-16-en.

2 OECD (2013), "Business $R$ and D", in OECD Science, Technology and Industry Scoreboard 2013: Innovation for Growth, OECD Publishing. http://dx.doi.org/10.1787/sti_scoreboard-2013-15-en. 
The relationship between the considered variables can be described by a logarithmic function (Figure 1).

Figure 1. the Relationship of the share of indirect state support for R\&D through tax incentives and the share of business expenses on $\mathrm{R} \& \mathrm{~d}$ in GDP

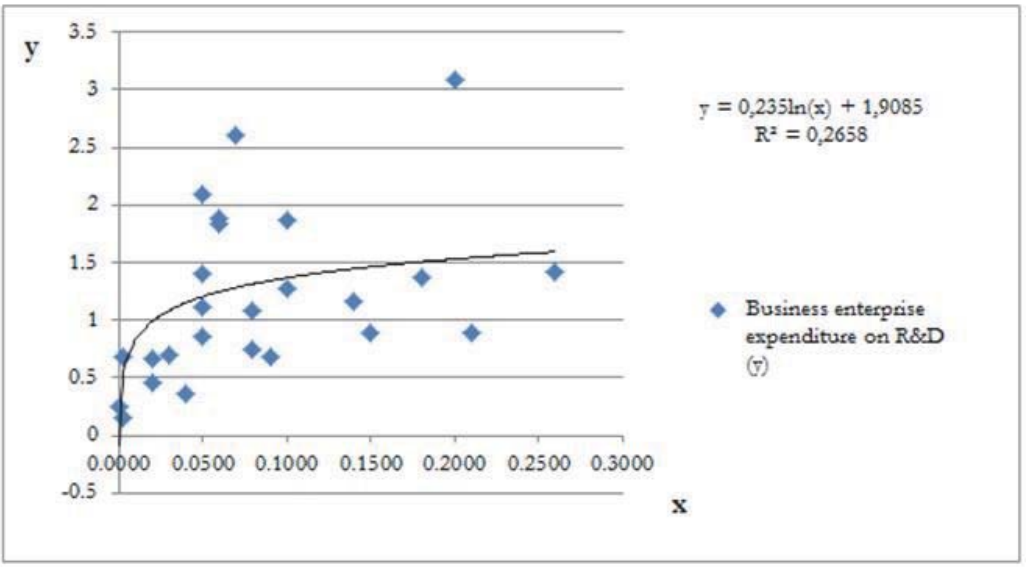

Figure 1 shows the smoothing of the trend line, based on a logarithmic function. The value of coefficient of determination R2 increases to 0,2658 , but it is not enough to draw a conclusion about the relation of explanatory and dependent variable.

\section{Analysis Result}

Analysis of the innovation activity dynamics of countries using tax incentive measures, shows that not in all cases, they lead to an increase in the share of research and development in the cost structure of enterprises. For example, a retrospective analysis of OECD data showed that in 2010 and 2011, countries such as Spain and Canada has provided significant support to the business sector by indirect methods of stimulating R\&D and use of RIA. However, as far as the activity of the business sector to conduct their own R\&D these countries are far from leading positions (27 and 22, respectively, of the 36 countries included in the OECD sample). Moreover, in Canada there is a decrease of activity of the business sector in the financing of its own R\&D compared with the data in 2001. In Finland, on the other hand, the amount of fiscal stimulus is small, however, according to the 2011 it was the 3rd country out of 36 in terms of Business enterprise expenditure on R\&D. In Norway, despite the attempts to increase the share of the private sector in R\&D expenditure for the period 2005 - 2012 years, the proportion of business expenditure declined from 47 to $44 \%$ (Klavdienko, 2014). Thus, a retrospective analysis of statistical data shows that it is not always the use of indirect incentives gives the desired effect.

Periodically countries using tax incentives for R\&D have to adjust instruments of indirect support by introducing additional benefits, or cancel the earlier ones. For example, tax deductions for R\&D were abolished in 2013 in such countries as Mexico, New Zealand, Chile. In Austria tax incentives for R\&D, that had been in force earlier, also have been cancelled. In Slovenia in 2012 regional tax incentives for enterprises engaged in R\&D spending were abolished, but because of the introduction of the tax credit for all high-tech enterprises of the country without reference to the region. In Canada, even in 2013, the scheme of accelerated depreciation was operating in which the fixed assets, which are at least $90 \%$, were used in research and development and could be written off fully expensed in the year of acquisition. Since 2014 Canada decided to abandon accelerated depreciation for R\&D expenses which had been in force before.

The study of international experience has shown that an effective state policy in the sphere of R\&D stimulating is a combination of direct and indirect instruments and it should be subjected to periodic review in accordance with the analysis of changes in the main macroeconomic indicators showing the level of "innovation" of analysed economy.

The Russian economy is facing the same problems as other countries that make extensive use of tax incentives for business R\&D expenditure. The whole wide range of tax incentives does not have undue influence on the growth of the share of business R\&D expenditure. One of the problems existing in Russia is a lack of interest from the business sector enterprises in putting on the balance the RIA obtained free of charge from third parties or created in the course of its activities. The companies' reluctance to put the RIA on the balance is caused by the obligatoriness to pay the income tax 
from non-operating income. However, a large number of RIA has been accumulated on the state balance that was created in the state budget and has not been yet practically applied. As a result, the RIA become obsolete, losing their relevance and practical utility.

The solution to this problem is seen in the introduction of the comprehensive tax measures, for example an exemption from income tax revenue resulting from the statement the on the balance RIA which is received free of charge or previously created by the enterprise itself with simultaneous cancellation of the accelerated depreciation for such RIA to avoid significant losses to the state budget. This will increase the demand from the business sector for intellectual property created by the state and granted to companies free of charge, as well as encourage businesses to put on the balance RIA, previously developed and identified in the inventory.

It should be noted that in many areas of science and technology RIA are complex objects that can include multiple parts or components, platforms, add-ons and modifications. This may relate, for example, to RIA created in information technology, electronics and informatics. Such RIA can be called complex objects of intellectual property, which includes such a component as a basic RIA. Each time, implementing new and improved modification RIA entrepreneur pays income tax on their sales, including sales to the basic component of RIA in the new version. One of the options of tax benefit may be the exemption from income tax of income from the sale of the basic component of RIA.

The analysis showed that assessing the positive impact of the introduction of indirect measures to encourage businesses to increase spending on R\&D through the tax incentives is a difficult task. Nevertheless, it can be argued that the introduction of tax incentives for R\&D expenditure of business may give a positive socio-economic impact. As a result of the introduction of tax incentives business enterprises obtain additional monetary funds which can be used to create new jobs, provide further increase in R\&D spending, stimulate enterprises to use RIA in their production of goods and services. It also stimulates the growth in the number of transactions with RIA and the development of RIA market. All these socio-economic effects lead to additional budget revenues and enhance the level of "innovation" of the economy.

\section{Conclusions}

Tax incentives are one of the instruments to encourage the market development of the RIA, which can have a positive impact on the supply of new products and technologies, as well as on their demand. It can be considered as an incentive for business sector to use RIA for the production (new equipment, materials, technology, formula and so on), to implement their own R\&D to create new products and technologies and to attract research organizations to conduct joint R\&D, i.e. the cooperation of business and science. These measures are aimed at improving the instruments to stimulate spending on R\&D both in traditional and innovative sectors of the economy. The latest contribute to the creation of the breakthrough R\&D and the high-tech production development, re-industrialization, as well as RIA commercialization, which in turn leads to an increased technological competitiveness of the country.

\section{References}

Gokhberg L., Kitova G., Rud' V. (2014). Tax Incentives for R\&D and Innovation: Demand versus Effects. Foresight, 8, 3, $18-41$.

Klavdienko V. (2014) The formation of the innovation system in Norway: the main features of the current stage. Society and economy, 10, 83-95.

Feoktistova T.V. (2014) Controversial Aspects of Tax Regulators of Innovation in Russia. National interests: priorities and security, 19, 32-39. 